\title{
Diyabetik Maküla Ödeminde İntravitreal Bevacizumab Tedavisinin Santral Maküla Kalınlığı ve Santral Retina Duyarılığı Üzerine Etkisi
}

The Effect of Intravitreal Bevacizumab Treatment on Central Macular Thickness and Central Retinal Sensitivity in Diabetic Macular Edema

\author{
Hatice Daldal ${ }^{1}$ iD , Yavuz Kamil Bardak² \\ 1 Göz Hastalıkları Anabilim Dalı, Uşak Üniversitesi Tıp Fakültesi, Uşak/Türkiye \\ 2 Göz Hastalıkları Kliniği, İstanbul Dünya Göz Hastanesi, İstanbul/Türkiye
}

\section{ÖzeT}

AMAÇ: Diyabetik maküla ödeminde (DMÖ) intravitreal bevacizumab (IVB) tedavisinin en iyi düzeltilmiş görme keskinliği (EIDGK), santral maküla kalınlığı (SMK) ve santral retina duyarlıığı (SRD) üzerine etkisini değerlendirme.

GEREÇ VE YÖNTEM: DMÖ olan 12 hastanın 16 gözüne IVB tedavisi uygulandı. Hastaların EIDGK, SMK, SRD ölçümleri tedaviden önce, birinci hafta, birinci ay ve üçüncü ayda yapıldı.

BULGULAR: Yaş ortalaması 60,8 \$5,7 yıl idi. EIDGK ortalaması başlangıçta ve enjeksiyondan 1 hafta, 1 ay, 3 ay sonra sırasıyla

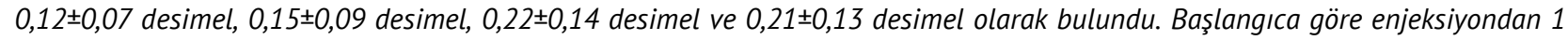
hafta, 1 ay ve 3 ay sonra EiDK'deki artış istatistiksel olarak anlamlı idi (p<0,05). Santral maküla kalınlığı ortalaması başlangıçta ve

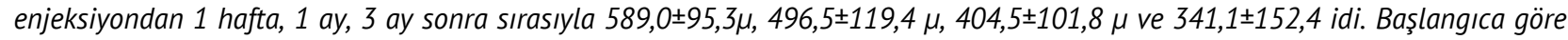
enjeksiyondan 1 hafta, 1 ay ve 3 ay sonra santral maküla kalınlığında azalma istatistiksel olarak anlamlı idi $(p<0,05)$. Santral retina duyarlılığı ortalaması başlangıçta ve enjeksiyondan 1 hafta, 1 ay, 3 ay sonra sırasıyla 14,7 $\pm 5,4 d B, 15,3 \pm 4,7 d B, 15,3 \pm 4,8$ $d B, 16,3 \pm 5,6 d B$ idi. Enjeksiyon sonrası 1. hafta, 1. ay ve 3. ay santral retina duyarlılıklarında artma gözlendi. Ancak başlangıca göre enjeksiyondan 1 hafta ve 3 ay sonra santral retina duyarlılığında artma istatistiksel olarak anlamlı idi $(p<0,05)$.

SONUÇ: Çalışmamızda IVB sonrası EIDGK ve SRD'de artış, SMK'da azalma gözlenmiştir. Bevacizumab erken dönemde diyabetik maküla ödeminde görsel, anatomik, fonksiyonel olarak fayda sağlamaktadır. Bevacizumab diyabetik maküla ödeminde etkili ve güvenilir bir tedavi yöntemidir. Diğer çalışmaların aksine bu çalışmada maküla eşik testi ile SRD değerlendirildi. Bevacizumabın fonksiyonel etkisi SRD ölçülerek değerlendirilebilir.

Anahtar Kelimeler: bevacizumab, diyabetik retinopati, maküla ödemi

\section{ABSTRACT}

OBJECTIVE: To evaluate effects of intravitreal bevacizumab (IVB) on best corrected visual acuity (BCVA), central macular thickness (CMT) and central retinal sensitivity (CRS) in diabetic macular edema (DME).

MATERIALS AND METHODS: 16 eyes of 12 patients with DME received IVB treatment. BCVA, CMT, CRS measurement of patients were performed before therapy, at first week, first month and third month.

RESULTS: The mean age was 60.8 \pm 5.7 years. The mean BCVA at baseline, 1 week,1 month, 3 month after injection were $0.12 \pm 0.07$ decimal, $0.15 \pm 0.09$ decimal, $0.22 \pm 0.14$ decimal and $0.21 \pm 0.13$, respectively. The increases in visual acuities from baseline at 1 week, 1 month and 3 month after injection were statistically significant ( $p<0,05)$. The mean CMT at baseline, 1 week, 1 month, 3 month after injection were $589.0 \pm 95.3 \mu, 496.5 \pm 119.4 \mu, 404.5 \pm 101.8 \mu$ and $341.1 \pm 152.4$, respectively. The decreases in CMT from baseline at 1 week, 1 month and 3 month after injection were statistically significant $(p<0.05)$. The mean CRS at baseline, 1 week, 1 month, 3 month after injection were 14.7 $\pm 5.4 d B, 15.3 \pm 4.7 d B, 15.3 \pm 4.8 d B, 16.3 \pm 5.6 d B$ respectively. Increase in CRS from baseline at 1 week and 3 month after injection was statistically significant $(p<0.05)$.

CONCLUSION: In our study increase in BCVA, decrease in CMT and increase CRS were observed after IVB. IVB provides visual, anatomic and functional benefits DME in early period. Bevacizumab is an effective and safe treatment method in DME. In this study, unlike other studies, CRS was evaluated using the macular threshold test. The functional efficacy of bevacizumab can be followed up by measuring CRS.

Keywords: bevacizumab, diabetic macular edema, retinal sensitivity

Yazışma Adresi/Address for Correspondence: Hatice Daldal, MD, Uşak Üniversitesi Tıp Fakültesi, Göz Hastalıkları Uşak /Türkiye E-Posta/E-Mail: drhdaldal@hotmail.com || Tel: +905332420059 


\section{GíRiş}

Diyabetik retinopati gelişmiş ülkelerde $40-65$ yaş grubunda ortaya çıkan körlüklerde önde gelen sebeptir (1). Diyabetik hastalarda görme kaybının başlıca nedeni diyabetik maküla ödemidir (DMÖ) (2).

DMÖ'de klasik tedavi seçenekleri sıkı kan şekeri regülasyonu ve lazer fotokoagülasyon (LFK) tedavisidir $(3,4,5,6)$. Bazı DMÖ hastalarında LFK'nin yetersiz kalması araştırmacıları, intravitreal steroid, anti-vasküler endotelyal büyüme faktörü (anti-VEGF) enjeksiyonu, protein kinaz C inhibitörleri, intravitreal steroid implantı, pars plana vitrektomi gibi tedavi metotlarını araştırmaya yönlendirmiştir (7).

DMÖ'de anti-VEGF ajan olan bevacizumab kullanımı son zamanlarda güncellik kazanan alternatif bir tedavi yöntemidir. Bevacizumab DMÖ haricinde pek çok hastalıkta kullanılmaktadır. Senil maküla dejenerasyonunda, proliferatif diyabetik retinopatide, psödofakik kistoid maküla ödeminde de başarılı sonuçlar elde edilmiştir $(8,9,10,11)$.

Bu çalışmada DMÖ'de intravitreal bevacizumab (IVB) uygulamasının erken dönemde görme keskinliği, santral maküla kalınlığı ve santral retina duyarlılığı üzerine olan etkileri değerlendirilmiştir.

\section{GEREÇ VE YÖNTEM}

Bu çalışmada Ocak 2011-Haziran 2011 tarihleri arasında diyabetik maküla ödemi tanısı ile kliniğimizde takip edilen 12 hastanın 16 gözü prospektif olarak incelendi.

DMÖ nedeniyle LFK tedavisi uygulanmış ve maküla ödemi devam eden veya LFK uygulanmamış olsa da maküla ödemi bulunan, Erken Tedavi Diyabetik Retinopati Çalışması (12) sınıflamasına göre klinik olarak anlamlı maküla ödemi tanımına uyan hastalar çalışmaya dahil edildi. Katarakt, kornea opasitesi, glokom gibi görme keskinliğini etkileyebilecek patolojisi bulunan, üveit, retinal ven tıkanıklığı, senil maküla dejenerasyonu, epiretinal membran gibi maküla ödemine neden olabilecek patolojisi olan, son 6 ay içinde katarakt cerrahisi geçiren, lazer kapsülotomi ve panretinal LFK yapılan, kontrolsüz diyabet ve hipertansiyonu olan hastalar çalışma kapsamı dışında bırakıldı. Süleyman Demirel Üniversitesi Tıp Fakültesi Klinik Araştırmalar Etik Kurulu tarafından 09/07/2019 tarihli, 215 sayılı etik kurul onayı alındı.

Tüm gözlere bir kez intravitreal 1,25mg/0,05ml bevacizumab (Altuzan, Genentech, San Francisco-USA) enjeksiyonu yapıldı. Enjeksiyon öncesinde hastaların detaylı oftalmolojik muayeneleri yapıldı. En iyi düzeltilmiş görme keskinliği (EiDGK) Snellen eşeli ile desimel olarak değerlendirildi. Göz içí basıncı (GIB) ölçümü Goldmann aplanasyon tonometrisi ile ölçüldü. Biyomikroskobik ön segment muayeneleri yapıldı. Fundus muayeneleri 90D lens kullanılarak yapıldı. Fundus floresein anjiyografileri (FFA) çekildi. Spektral optik koherens tomografi (Ophthalmic Technologies Inc. [OTI], Toronto, Ontario, Canada) cihazı ile santral maküla kalınlığı (SMK) ölçüldü. Santral retina duyarlılığı Bilgisayarlı Görme Alanı (HFA 740) Maküla Eşik Testi ile santral 16 noktanın retinal duyarlılık ortalaması alınarak belirlendi. Enjeksiyon sonrası 1. hafta, 1. ay, 3. aylarda EIDGK, SMK, santral retina duyarlılığına bakıldı. Enjeksiyon sonrası 2. gün, 1. hafta, 1. ay, 3. aylarda Gï'leri ölçüldü.

Veriler, Statistical Package for Social Science (SPSS) 15.0 programında tanımlayıcı istatistik, Mann-Whitney $U$, Friedman, Wilcoxon ve Pearson korelasyon testleri ile analiz edildi. İstatistiksel analizlerde anlamlılık değeri $p<0,05$ olarak kabul edildi.

\section{BULGULAR}

Çalışmaya DMÖ olan 6'sı $(\% 50,0)$ kadın, 6'sı $(\% 50,0)$ erkek olmak üzere toplam 12 hastanın 16 gözü dahil edildi. 52-71 yaş aralığında olan hastaların yaş ortalaması 60,8 $\pm 5,7$ yıl olarak tespit edildi. Hastaların tamamı tip 2 diyabet grubundaydı ve hastalık süresi en az 5, en fazla 12 yıl olmak üzere ortalama $8,3 \pm 2,6$ yıl idi. Çalışmaya dahil edilen hastaların gözlerinin 13'ünde $(\% 81,3)$ non proliferatif diyabetik retinopati, 3'ünde $(\% 18,7)$ ise proliferatif diyabetik retinopati mevcuttu. Hastaların 8'inde unilateral $(\% 66,6)$, 4'ünde $(\% 33,3)$ ise bilateral DMÖ mevcuttu. $12(\% 75,0)$ göze daha önceden LFK uygulanmış, 4 göze $(\% 25,0)$ ise uygulanmamıştı. Olguların cinsiyete göre yaş ortalamaları karşılaştııılığında, aralarında istatistiksel fark saptanmadı $(p=0,936)$

Hastaların enjeksiyon öncesi EIDGK ortalaması 0,12 $\pm 0,07$ desimel iken, enjeksiyon sonrası 1.hafta 0,15 $\pm 0,09$ desimel, 1. ay $0,22 \pm 0,14$ desimel ve 3 .ay $0,21 \pm 0,13$ desimel olarak bulundu. Tüm EiDGK ortalamaları karşılaştırıldığında aralarında istatistiksel fark anlamlı tespit edildi $(p<0,0001)$ (Grafik 1). Enjeksiyon öncesi EIDGK'ye göre enjeksiyon sonrası 1.hafta, 1.ay ve 3.ay görme keskinliklerinde artış saptandı. EiDGK'de görülen tüm bu artışlar istatistiksel olarak anlamlı tespit edildi $(p<0,05)($ Tablo1). 
Grafik 1. Enjeksiyon öncesi ve sonrasındaki EIDGK değişimlerinin dağılımı

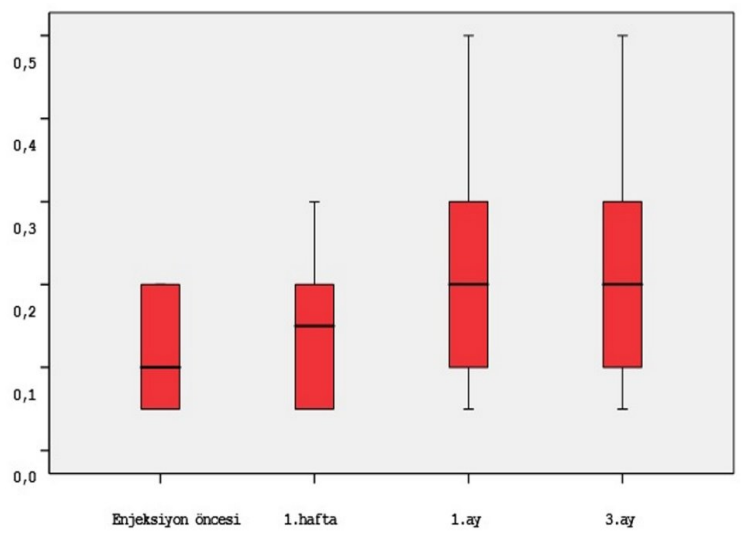

Tablo 1. Enjeksiyon öncesi en iyi düzeltilmiş görme keskinliği değerlerinin 1. hafta, 1. ay ve 3. ay en iyi düzeltilmiş görme keskinliği değerleri ile ikili karşılaştırılması

\begin{tabular}{|ccc|}
\hline Tedavi Zamanı & $\begin{array}{c}\text { Görme Keskinliği } \\
\text { (Ort. } \pm \text { SS) }\end{array}$ & $\mathbf{p}^{*}$ \\
Enjeksiyon öncesi & $0,12 \pm 0,07$ & $\mathbf{0 , 0 4 6}$ \\
1.Hafta & $0,15 \pm 0,09$ & \\
Enjeksiyon öncesi & $0,12 \pm 0,07$ & $\mathbf{0 , 0 0 2}$ \\
1. Ay & $0,22 \pm 0,14$ & \\
Enjeksiyon öncesi & $0,12 \pm 0,07$ & $\mathbf{0 , 0 0 5}$ \\
3. Ay & $0,21 \pm 0,13$ & \\
\hline
\end{tabular}

Birinci haftada 4 gözde $(\% 25,0)$ EiDGK tedavi öncesine göre artarken, 12 gözde $(\% 75,0)$ ise aynı kaldı 1 . ayda 12 gözde $(\% 75,0)$ EiDGK tedavi öncesine göre artarken, 4 gözde $(\% 25,0)$ ise aynı kaldı. 3. ayda 10 gözde $(\% 62,5)$ EiDGK tedavi öncesine göre artarken, 6 gözde $(\% 37,5)$ ise aynı kaldı.

Enjeksiyon öncesi GiB değeri ortalamasına göre 1. hafta, 1. ay ve 3. ay GiB ortalamaları arasında istatistiksel fark saptanmadı $(p=0,580)$.

Hastaların enjeksiyon öncesi santral maküla kalınlığı ortalaması 589,0 $\pm 95,3 \mu$ iken, enjeksiyon sonrası 1.hafta $496,5 \pm 119,4 \mu$, 1 .ay $404,5 \pm 101,8 \mu$ ve 3 .ay $341,1 \pm 152,4 \mu$ olarak bulundu. Enjeksiyon öncesine kıyasla sonrasında santral maküla kalınlığı ortalamaları azaldı ve bu azalma istatistiksel olarak anlamlı tespit edildi $(p<0,0001)$ (Grafik 2).

Yapılan ikili karşılaştırmalara göre enjeksiyon öncesi santral maküla kalınlığına göre, enjeksiyon sonrası 1. hafta, 1. ay ve 3. ay santral maküla kalınlıklarında azalma saptandı. Ölçülen santral maküla kalınlıklarında görülen tüm bu azalmalar istatistiksel olarak anlamlı tespit edildi $(p<0,05)$ (Tablo 2).
Grafik 2. Enjeksiyon öncesi ve sonrası santral maküla kalınlığı değişimlerinin dă̆ııımı

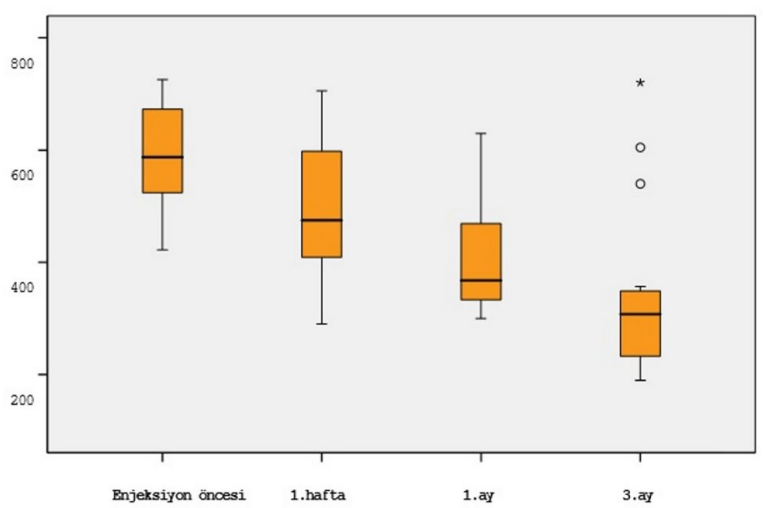

Tablo 2. Hastaların enjeksiyon öncesi santral maküla kalınlığ değerlerinin 1. hafta, 1. ay ve 3. ay santral maküla kalınlı̆̆ değerleri ile ikili karşılaştırılması

\begin{tabular}{|ccc|}
\hline Tedavi Zamanı & $\begin{array}{c}\text { Santral Maküla Kalınlığı } \\
(\mu)(\text { Ort. } \pm \text { SS })\end{array}$ & $\mathbf{P}^{*}$ \\
Enjeksiyon öncesi & $589,0 \pm 95,3$ & \\
1.Hafta & $496,5 \pm 119,4$ & $\mathbf{0 , 0 0 0}$ \\
Enjeksiyon öncesi & $589,0 \pm 95,3$ & \\
1. Ay & $404,5 \pm 101,8$ & $\mathbf{0 , 0 0 0}$ \\
Enjeksiyon öncesi & $589,0 \pm 95,3$ & \\
3. Ay & $341,1 \pm 152,4$ & $\mathbf{0 , 0 0 1}$ \\
\hline
\end{tabular}

Enjeksiyon sonrası 1. haftada enjeksiyon öncesine göre hastaların tümünde santral maküla kalınlığında azalma saptandı. Hastaların tümünde enjeksiyon sonrası 1.ayda tedavi öncesine göre santral maküla kalınlığında azalma saptandı. Enjeksiyon sonrası 3. ayda 14 gözde $(\% 87,5)$ santral maküla kalınlığı tedavi öncesine göre azalırken, 2 gözde $(\% 12,5)$ ise arttı. Bir hastanın enjeksiyon öncesi ve sonrası 1. haftada, 1. ayda, 3. ayda santral maküla kalınlığ ve EIDGK değişimi gösterilmektedir (Resim1, 2, 3, 4).

Resim 1. Enjeksiyon öncesi SMK $605 \mu$, EIDGK 0,2

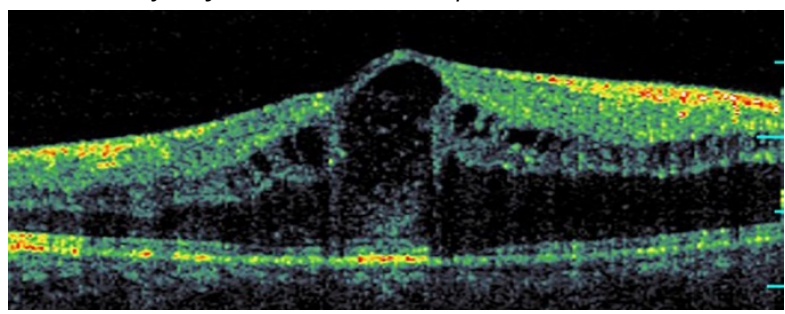

Resim 2. Enjeksiyon sonrası 1. haftada SMK $580 \mu$, EIDGK 0,2

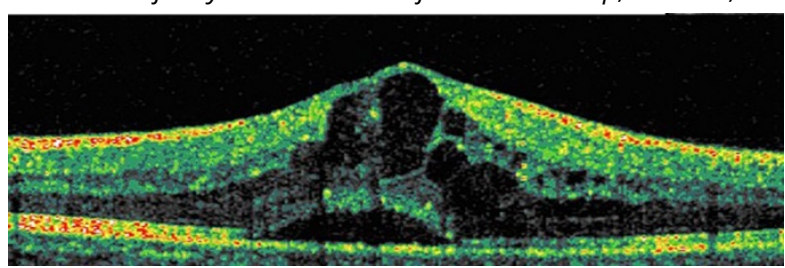


Resim 3. Enjeksiyon sonrası 1. ayda SMK $340 \mu$, EIDGK 0,4

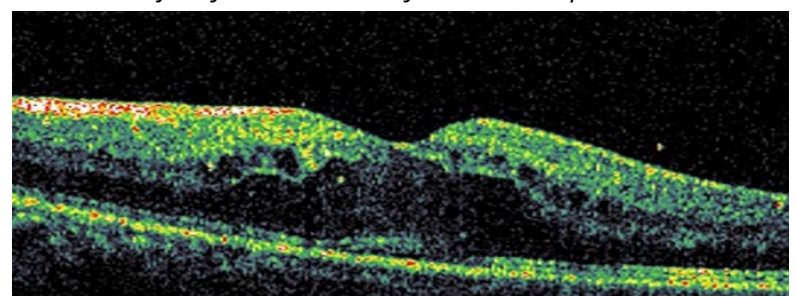

Resim 4. Enjeksiyon sonrası 3. ayda SMK $190 \mu$, EIDGK 0,4

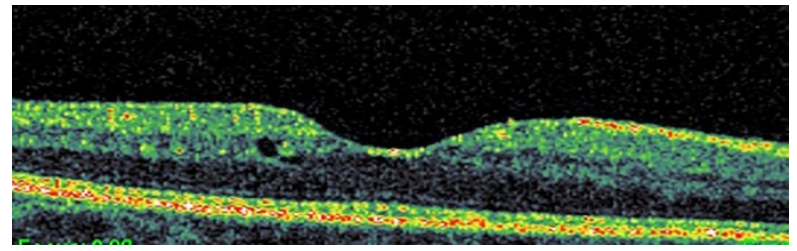

Hastaların enjeksiyon öncesi santral retina duyarlılığı ortalaması $14,7 \pm 5,4 \mathrm{~dB}$ iken, enjeksiyon sonrası 1.hafta $15,3 \pm 4,7 \mathrm{~dB}, 1$. ay $15,3 \pm 4,8 \mathrm{~dB}$ ve 3 . ay $16,3 \pm 5,6 \mathrm{~dB}$ olarak bulundu. Hastalarda enjeksiyon öncesine kıyasla sonrasında santral retina duyarlılığı ortalamalarında artış tespit edildi ve bu artış istatistiksel olarak anlamlı bulundu $(p=0,002)$ (Grafik 3). Yapılan ikili karşılaştırmalara göre enjeksiyon öncesi santral retina duyarlılığına göre, enjeksiyon sonrası 1. hafta, 1. ay ve 3. ay santral retina duyarlılıklarında artış saptandı. Ancak 1. hafta ve 3. ay ölçülen santral retina duyarlılığında görülen artışlarda istatistiksel anlamlılık tespit edildi $(p<0,05)$. Enjeksiyon öncesi ve 1. ay santral retina duyarlılığı ortalamaları karşılaştırıldığında ise istatistiksel fark saptanmadı $(p=0,103)$ (Tablo 3). Hastaların 12'sinde (\%75) 1. hafta santral retina duyarlılığı, tedavi öncesine göre artarken, 4'ünde (\%25) azaldı. Hastaların 12'sinde (\%75) 1. ay santral retina duyarlılığı, tedavi öncesine göre artarken, 4'ünde (\%25) azaldı. Hastaların 15'inde $(\% 93,7)$ 3.ay santral retina duyarlılığı, tedavi öncesine göre artarken, 1'inde $(\% 6,3)$ azaldı. Bir olgumuzun enjeksiyon öncesi ve sonrası 1. haftada, 1. ayda, 3. ayda santral retina duyarlılığı değişimi gösterilmektedir (Resim 5, 6, 7, 8).

Tablo 3. Enjeksiyon öncesi santral retina duyarlılığı değerlerinin 1.hafta, 1.ay ve 3.ay santral retina duyarlılığ değerleri ile ikili karşılaştırılması

\begin{tabular}{|ccc|}
\hline Tedavi Zamanı & $\begin{array}{c}\text { Santral Retina Duyarlılığı } \\
\text { (dB) (Ort. } \pm \text { SS) }\end{array}$ & $\mathbf{P}^{*}$ \\
Enjeksiyon öncesi & $14.7 \pm 5.4$ & \\
1.Hafta & $15,3 \pm 4,7$ & $\mathbf{0 , 0 4 4}$ \\
Enjeksiyon öncesi & $14,7 \pm 5,4$ & \\
1. Ay & $15,3 \pm 4,8$ & 0,103 \\
Enjeksiyon öncesi & $14,7 \pm 5,4$ & \\
3. Ay & $16,3 \pm 5,6$ & $\mathbf{0 , 0 0 2}$ \\
\hline
\end{tabular}

On gözde $(\% 62,5) 3$. ay FFA'da ölçülen sızıntı miktarı, tedavi öncesine göre azalırken, 5 gözde $(\% 31,2)$ aynı kalmış, 1 gözde $(\% 6,3)$ ise artmıştır. Hastalarda intravitreal enjeksiyon ile ilgili herhangi bir komplikasyon gözlenmedi.

Grafik 3. Enjeksiyon öncesi ve sonrası santral retina duyarlılığı değişimlerinin dağılımı

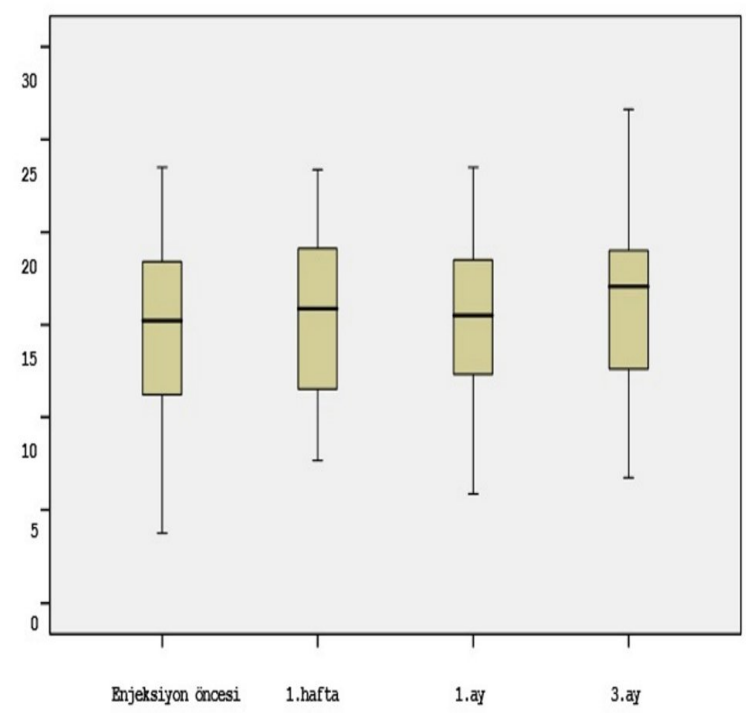

Resim 5. Tedavi öncesi maküla eşik testi

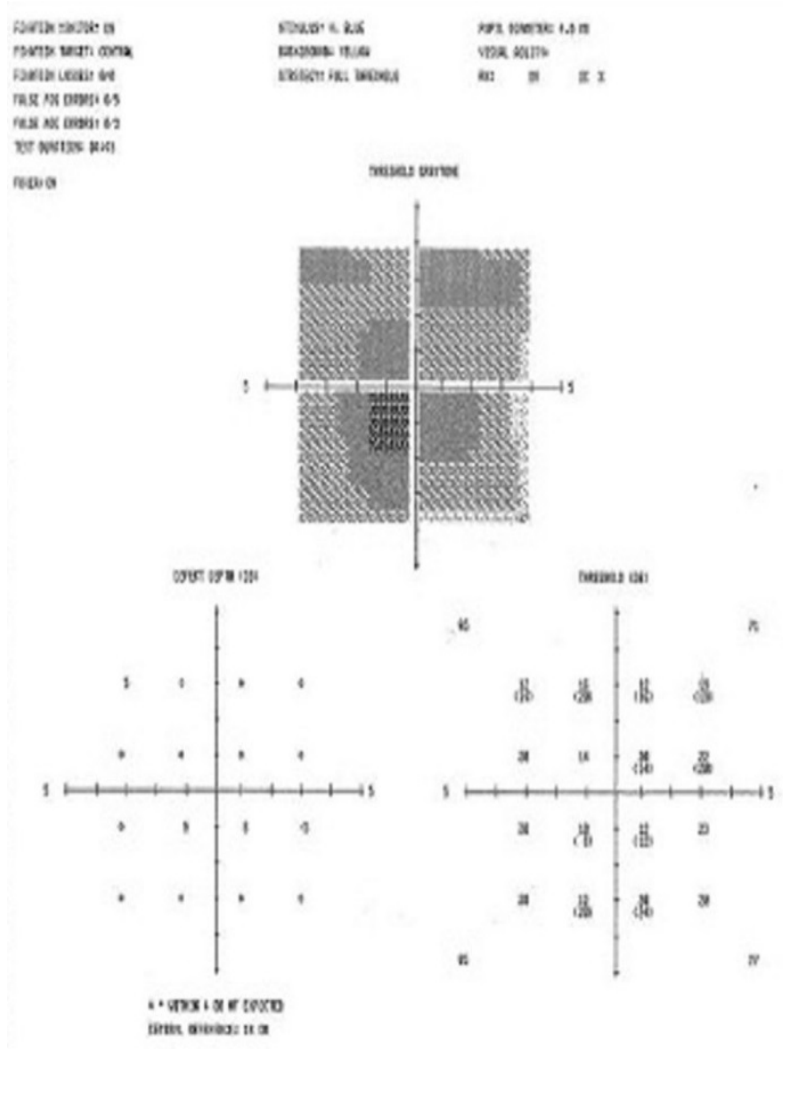


Resim 6. Tedavi sonrası 1. haftada maküla eşik testi

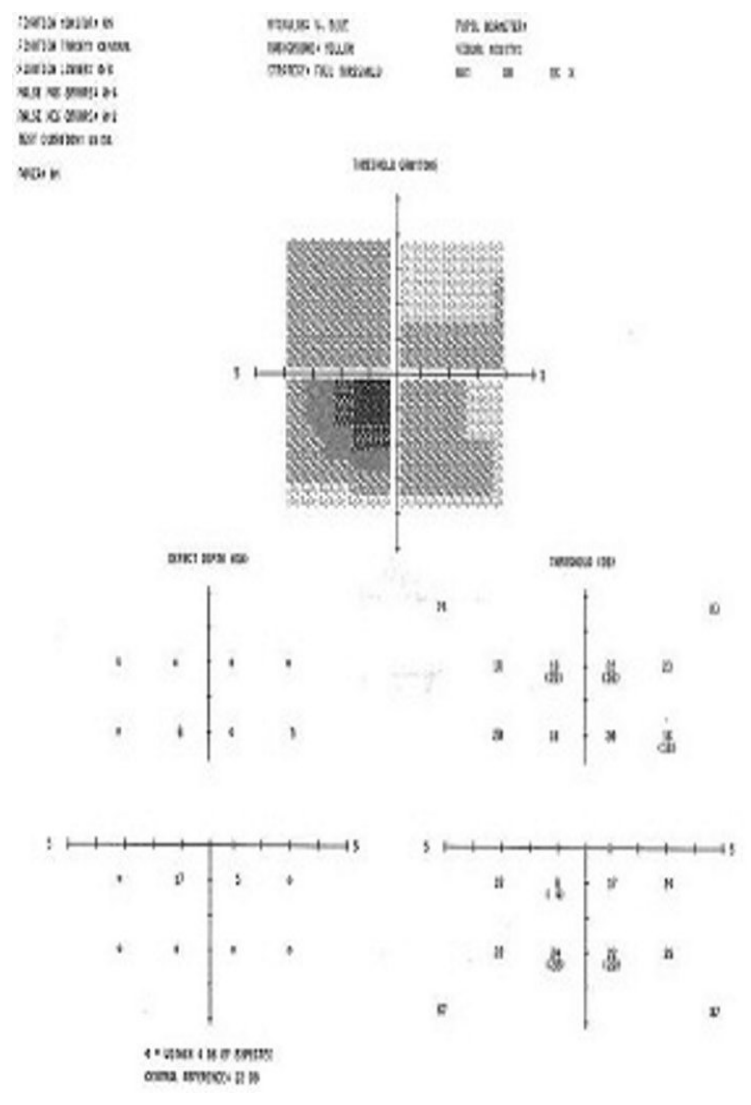

Resim 7. Tedavi sonrası 1. ayda maküla eşik testi

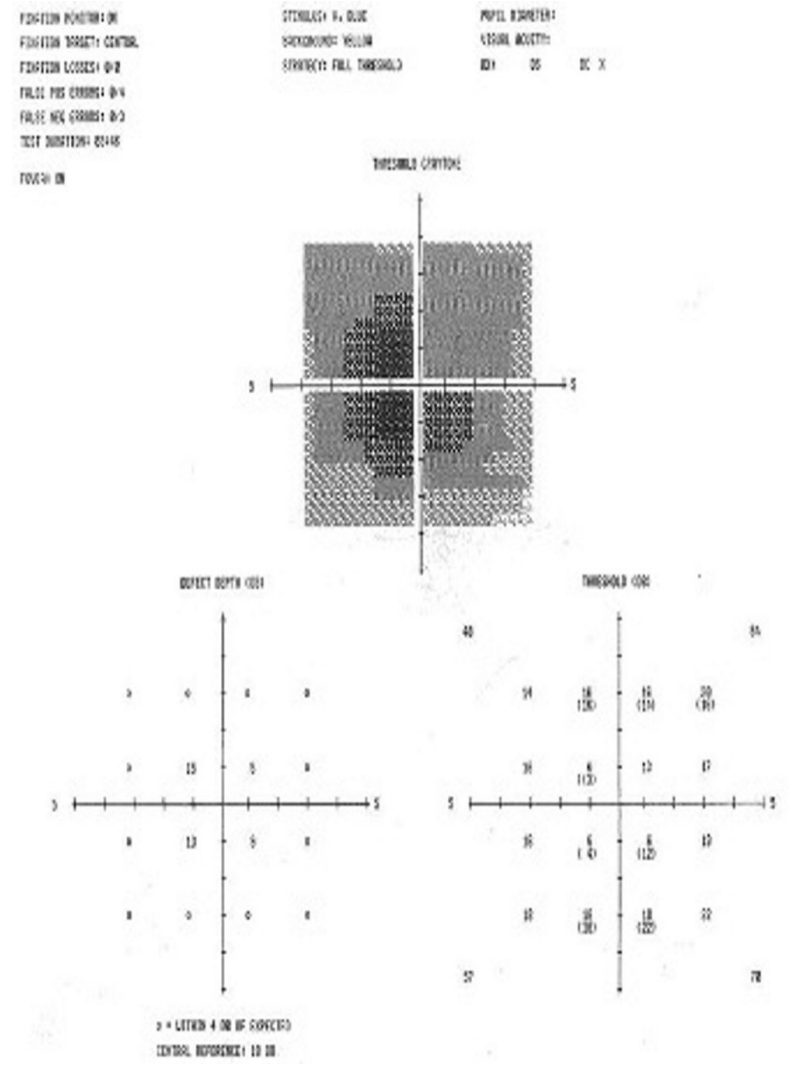

Resim 8. Tedavi sonrası 3. ayda maküla eşik testi

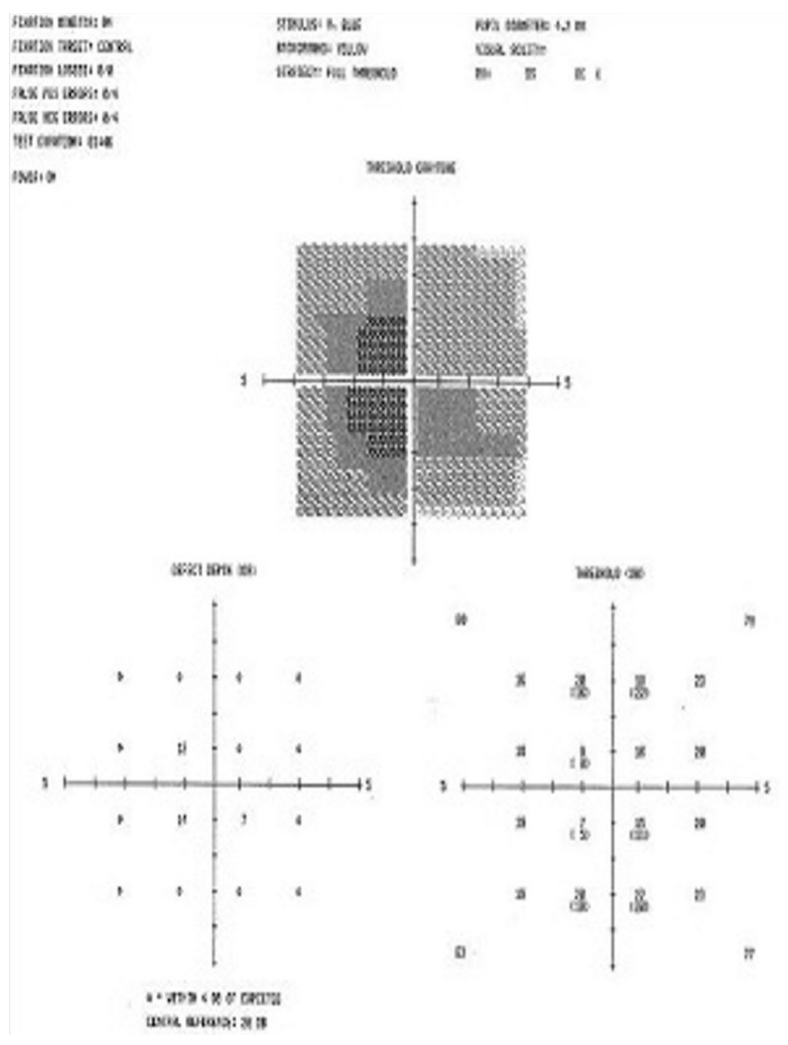

TARTIŞMA

Diyabetik retinopatideki görme kaybından sorumlu iki major patolojik olay retinal vasküler yüksek geçirgenlik sonucu oluşan diyabetik maküla ödemi ve retina neovaskülarizasyonlarıdır. Potent bir anjiyogenik uyarıcı ve vasküler geçirgenlik faktörü olan VEGF bu durumların her ikisine yol açabilmektedir. Diyabetik maküla ödeminin derecesi arttıkça aköz hümördeki VEGF düzeylerinde doğru orantılı bir artış olmaktadır. Günümüzde retina neovaskülarizasyonu ile seyreden hastalıkların başında gelen diyabetik retinopati ve retina ven tıkanıklıklarında anti-VEGF tedavisi endikasyon dışı olarak uygulanmakta ve klinik kullanımda olan değişik anti-VEGF ilaçlar ile değişken yanıtlar elde edilmekle birlikte başarılı sonuçlar bildirilmektedir. Aynı zamanda prematüre retinopatisi, Coats hastalığı, ailesel eksüdatif vitreoretinopati, inkontinentia pigmenti gibi pediatrik vitreoretinal hastalıklarla ilgili çalışmalar da mevcuttur (13).

Bevacizumab diyabetik retinopatide maküla ödemi, iris neovaskülarizasyonları, retina ve disk neovaskülarizasyonları varlığında ve vitrektomi sonrası reproliferasyon, tekrar kanamadan koruma amacıyla kullanılmaktadır. iVB enjeksiyonunun lazer 
fotokoagülasyon, intravitreal triamsinolon (IVTA) enjeksiyonu, vitrektomi gibi tedavilere cevap vermeyen diffüz DMÖ olanlarda faydalı olduğu bildirilmiştir (8).

Pek çok çalışma ile bevacizumabın DMÖ tedavisinde anatomik ve görsel başarı sağladığı gösterilmiştir.

Haritoglou ve ark. DMÖ olan 51 hastadan oluşan çalışmalarında hastalara 1,25 mg/0,05ml iVB enjeksiyonu uygulanmış, 16 hastaya en az 2 enjeksiyon yapılmıştır. Tüm hastaların daha önceden \%35'i fokal lazer tedavisi, \%37'si panretinal lazer tedavisi, \%12'si vitrektomi ve \%33'ü IVTA enjeksiyonu gibi değişik tedaviler aldığı belirtilmiştir.

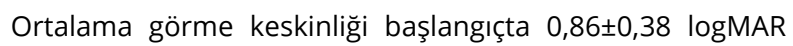
iken, tedavi sonrası 6 . haftada $0,75 \pm 0,37 \log M A R^{\prime} a(p=0,001)$

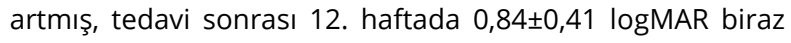
gerileme görülmüştür. 6 haftalık izlemde \%29'unda, 12 haftalık izlemde ise \%26'sında en az 3 sıralık görme artışı elde etmişlerdir. Ortalama santral retinal kalınlık başlangıçta $501 \pm 163 \mu$ iken, tedavi sonrası 2 . haftada $425 \pm 180 \mu(p=0,002)$, 6. haftada $416 \pm 180 \mu(p=0,001), 12$. haftada $377 \pm 117 \mu(p=0,001)$ olarak düşüş göstermiştir. Sonuç olarak bu çalışmada LFK, IVTA enjeksiyonu veya vitrektomi gibi daha önceki tedavilere yanıt vermeyen persistan diffüz DMÖ olgularında bile IVB enjeksiyonunun görme keskinliğinde düzelme, retinal kalınlıkta azalma sağladığı gözlenmiştir (8).

Arevalo ve ark. diffüz DMÖ olan 115 hastanın 139 gözünü kapsayan retrospektif, çok merkezli çalışmalarında, hastalara 1,25-2,5mg intravitreal bevacizumab enjeksiyonu uygulanmış ve yirmi dört ay takip sonucunda görme keskinliği ve SMK değişiklikleri incelenmiştir. Göz başına ortalama IVB enjeksiyon sayısı 5,8 olarak bulunmuştur. 1,25 mg IVB uygulanan grupta ortalama görme keskinliği başlangıçta 20/150 iken, 1. ayda 20/107 ( $p<0,0001$ ), takip süresi sonunda 20/75 ( $p<0,0001)$ olarak bulunmuştur. 2,5 mg IVB uygulamasında da benzer değişiklikler gözlenmiştir. Başlangıçta 20/168 iken, 1. ayda 20/118 ( $p=0.02), 24$ ay sonunda 20/114 ( $p<0,0001)$ olarak bulunmuştur. 1,25 mg uygulanan grupta ortalama SMK başlangıçta 466,5 $\pm 145,2$ iken, 1 . ayda $332,2 \pm 129,6,24$ ay sonunda ise $286,6 \pm 81,5^{\prime} \mathrm{e}$ düşmüştür. $2,5 \mathrm{mg}$ uygulanan grupta da benzer sonuçlara varılmıştır. Sonuç olarak diffüz DMÖ'de 24 aylık takipte 1,25 veya $2,5 \mathrm{mg}$ dozda uygulanan IVB tedavisinin görme keskinliğinde, SMK'de, FFA'de stabilite veya düzelme sağladığı görülmüştür. Sonuçlar açısından 1,25 mg veya 2,5 mg dozda uygulama arasında fark saptanmamıştır (14).
Kook ve ark. kronik diffüz DMÖ olan 126 hastadan oluşan çalışmalarında hastalar 6-12 ay takip edilmiştir. Ortalama santral maküla kalınlığı başlangıçta $463 \mu$ iken, 6. ayda 374 $\mu^{\prime} a$, 12. ayda ise 357 $\mu^{\prime}$ a düşmüştür. Tedavi sonucunda maküla iskemisinde şiddetlenme görülmemiştir. Sonuç olarak kronik diffüz iskemik DMÖ olan olgularda dahi tekrarlayan bevacizumab enjeksiyonları ile santral retinal kalınlıkta uzun süreli düşüş sağlandığı gözlenmiştir (15).

Kumar ve Sinha çalışmalarında lazer tedavisi sonrası 20 göze 2 doz 1.25 mg bevacizumab enjeksiyonu uygulamışlar ve 3. ile 6. aydaki kontrollerde görme keskinliğinde enjeksiyon öncesine göre anlamlı artış ve santral foveal kalınlıkta enjeksiyon öncesine göre anlamlı düşüş saptamışlardır (16).

Soheilian ve ark. DMÖ olan daha önceden tedavi görmemiş 129 hastanın 150 gözünü kapsayan çalışmalarında IVB (50 göz), iVB/IVTA (50 göz), lazer tedavisi (50 göz) uygulanan 3 grup oluşturulmuştur. Gruplar da başlangıçtaki SMK'ye göre 3 subgruba ayrılmıştır (<250 $\mu, 250-349 \mu$, $\geq 350 \mu)$ dolayısıyla asıl tedavi grupları 3 subgruba ayrılmıştır. Tedavi öncesi ve sonrası $6,12,24,36$. haftalarda görme keskinliği ve SMK değerlendirilmiştir. Altı haftada tüm subgruplarda ortalama görme keskinliğinde düzelme saptanmıştır ve IVB grubunda diğer gruplardan daha fazla düzelme bulunmuştur $(P=0,002, P=0,003, P<0,001,<250,250-349$, $\geq 350 \mu$, subgruplarda sırasıyla). $12,24,36$. haftalarda $>350$ $\mu$ subgrubunda ve 24-. haftada 250-349 $\mu$ subgrubunda, ortalama görme keskinliği değişikliği iVB grubu lehine anlamlı düzeye ulaşmıştır ( $P=0,010, P=0,028, P<0,001$ ve $\mathrm{P}<0,001$ sırasıyla). Ortalama SMK'de 6. haftada ve 12 . haftada $\geq 350 \mu$ subgrubunda $(P<0,001$ and $P<0,001)$ IVB grubunda, 24. haftada 250-349 $\mu$ IVB/IVTA grubunda anlamlı düzelme görülmüştür $(P<0,001)(17)$.

Protokol T ve PACORES çalışmalarına göre bevacizumabın diyabetik maküla ödeminde etkin olduğu gösterilmiştir $(18,19)$. PACORES çalışmasının 5 yıllık sonuçlarına göre DMÖ tedavisinde bevacizumab tedavisi ile görme keskinliğinde \%70 oranında stabilizasyon veya düzelme olduğu gösterilmiştir (20).

Jafri ve ark.nın yaptığı çalışmada, lazer ve bevacizumab tedavisi karşılaştırılmış ve bevacizumab grubunda görme keskinliğinde artış 1. ve 2. ayda erken dönemde görülürken, lazer grubunda artış 3. ayda gözlenmiştir. Altıncı ayda EIDGK'deki artışta gruplar arasında istatistiksel olarak fark saptanmamıştır (21). 
Kriechbaum ve ark.nın çalışmasında, 30 DMÖ hastasında bevacizumab ve triamsinolon tedavisi karşılaştırılmış ve santral retinal kalınlıkta aynı oranda azalma gözlenmiştir (22).

Çalışmamızda hastaların enjeksiyon öncesi EIDGK

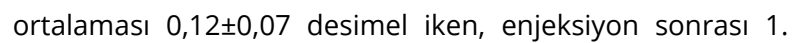
hafta $0,15 \pm 0,09$ desimel, 1 . ay $0,22 \pm 0,14$ desimel ve 3 . ay $0,21 \pm 0,13$ desimel olarak bulundu. Tüm EIDGK ortalamaları karşılaştırıldı̆̆ında aralarında istatistiksel fark anlamlı tespit edildi $(p<0,0001)$. Hastaların enjeksiyon öncesi santral maküla kalınlığı ortalaması 589,0 $\pm 95,3 \mu$ iken, enjeksiyon sonrası 1. hafta $496,5 \pm 119,4 \mu, 1$. ay $404,5 \pm 101,8 \mu$ ve 3 . ay $341,1 \pm 152,4 \mu$ olarak bulundu. Enjeksiyon öncesine kıyasla sonrasında santral maküla kalınlığı ortalamaları azaldı ve bu azalma istatistiksel olarak anlamlı tespit edildi $(p<0,0001)$. Hastaların enjeksiyon öncesi santral retina duyarlılığı ortalaması $14,7 \pm 5,4 \mathrm{~dB}$ iken, enjeksiyon sonrası 1 . hafta $15,3 \pm 4,7 \mathrm{~dB}, 1$. ay $15,3 \pm 4,8 \mathrm{~dB}$ ve 3 . ay $16,3 \pm 5,6 \mathrm{~dB}$ olarak bulundu. Hastalarda enjeksiyon öncesine kıyasla sonrasında santral retina duyarlılığı ortalamalarında artış tespit edildi ve bu artış istatistiksel olarak anlamlı bulundu $(p=0,002)$. Yapılan ikili karşılaştırmalara göre enjeksiyon öncesi santral retina duyarlılığına göre, enjeksiyon sonrası 1. hafta, 1. ay ve 3. ay santral retina duyarlılıklarında artış saptandı. Ancak 1. hafta ve 3. ay ölçülen santral retina duyarlılığında görülen artışlarda istatistiksel anlamlılık tespit edildi $(p<0,05)$. Enjeksiyon öncesi ve 1 . ay santral retina duyarlıı̆ı ortalamaları karşılaştırıldığında ise istatistiksel fark saptanmadı $(p=0,103)$. Hastaların $10^{\prime} u n d a(\% 62,5) 3$. ay floresein anjiyografide ölçülen sızıntı miktarı, tedavi öncesine göre azalırken, 5'inde $(\% 31,2)$ aynı kalmış, 1'inde $(\% 6,3)$ ise artmıştır.

\section{SONUÇ}

Sonuç olarak DMÖ için uygulanan bevacizumab tedavisinin görme keskinliğini arttırdı̆̆ı, SMK'yi azalttı̆̆ı, santral retinal duyarlıığı arttırdığı ve floresein anjiyografide sızıntıyı azalttı̆̆ı tespit edildi. Yapılan çalışmalardan farklı olarak çalışmamızda maküla eşik testi ile SRD değerlendirilmiştir. SRD ölçümü ile iVB tedavisinin fonksiyonel olarak etkinliğinin takibi yapılabilir. Sonuç olarak bevacizumabın erken dönemdeki görsel, anatomik, fonksiyonel açıdan etkili ve güvenilir olduğu saptandı. Fakat IVB'nin etkinliğinin tam olarak değerlendirilebilmesi için bu konuda daha geniş kapsamlı ve uzun vadeli, karşılaştırmalı çalışmalara ihtiyaç vardır.
Etik: Bu çalışmanın etik kurulu alınmıştır.

Ethics committee approval had been taken.

Yazar katkı durumu; Çalışmanın konsepti; HD, YKB, dizaynı; $H D$, YKB, Literatür taraması; HD, YKB, verilerin toplanması ve işlenmesi; HD, YKB, istatistik; HD, YKB, yazım aşaması; HD, YKB,

Author contribution status; The concept of the study; HD, YKB, design; $H D$, YKB, literature review; $H D$, YKB, collecting and processing data; $H D, Y K B$, statistics; $H D$, YKB, writing phase; HD, YKB,

Yazarlar arasında çıkar çatışması yoktur.

The author declares no conflict of interest.

Finansal Destek: yoktur / Funding: none

doi: https://doi.org/10.33713/egetbd.704103

\section{KAYNAKLAR}

1. Kim JW, Ai E. Diabetic retinopathy. In: Regillo CD, Brown GC, Flynn Jr HW, eds. Vitreoretinal disease, The Essentials, New York;Thime;1999:133-59.

2. Klein $R$, Klein BE, Moss SE. Visual impairment in diabetes. Ophthalmology 1984; 91:1-9.

3. Diabetes Control and Complication Trial Research Group. The effect of intensive treatment of diabetes on the development and progression of longterm complications in insulindependent diabetes mellitus. N Engl J Med 1993; 329:977-86.

4. UK Prospective Diabetes Study Group. Intensive bloodglucose control with sulphonylureas or insulin compared with conventional treatment and risk of complications in patients with type 2 diabetes. UKPDS 33. Lancet 1998; 352:837-53.

5. Photocoagulation for diabetic macular edema. Early Treatment Diabetic Retinopathy Study report number 1. Early Treatment Diabetic Retinopathy Study Research Group. Arch Ophthalmol 1985; 103:1796-806.

6. Photocoagulation treatment of proliferative diabetic retinopathy. Clinical application of Diabetic Retinopathy Study (DRS) findings, DRS Report Number 8. Diabetic Retinopathy Study Research Group. Ophthalmology. 1981; 88:583-600.

7. Pendergast SD, Hassan TS, Williams GA, Margherio RR, Ferrone PJ, Garretson BR, et al. Vitrectomy for diffuse diabetic macular edema associated with a taut premacular posterior hyaloid. Am J Ophthalmol 2000; 130:178-86.

8. Haritoglou C, Kook D, Neubauer A, Wolf A, Priglinger $S$, Strauss R, et al. Intravitreal bevacizumab (Avastin) therapy for persistent diffuse diabetic macular edema. Retina 2006; 26:9991005.

9. Avery RL, Pieramici DJ, Rabena MD, Castellarin AA, Nasir MA, Giust MJ. Intravitreal bevacizumab (Avastin) for neovascular age-related macular degeneration. Ophthalmology. 2006; 113:363-72.

10. Spaide RF, Fisher YL. Intravitreal bevacizumab (Avastin) 
treatment of proliferative diabetic retinopathy complicated by vitreous hemorrhage. Retina. 2006; 26:275-8.

11. Mason JO 3rd, Albert MA Jr, Vail R. Intravitreal bevacizumab (Avastin) for refractory pseudophakic cystoid macular edema. Retina. 2006; 26:356-7.

12. Early Treatment Diabetic Retinopathy Study Research Group. Focal photocoagulation treatment of diabetic macular edema. Relationship of treatment effect to fluorescein angiographic and other retinal characteristics at baseline: ETDRS report no. 19. Arch Ophthalmol. 1995;113(9):1144-55.

13. Yılmaz G. Kuçukerdonmez CF. Anjiogenesis and VEGF. Ed: Karacorlu M, Karacorlu SA, Ozdemir H. Eye Disease and antiVEGF Treatment. Istanbul 2010:11-21.

14. Arevalo JF, Sanchez JG, Wu L, Maia M, Alezzandrini AA, Brito $M$, et al. Primary intravitreal bevacizumab for diffuse diabetic macular edema: the Pan-American Collaborative Retina Study Group at 24 months. Ophthalmology. 2009; 116(8):1488-97.

15. Kook D, Wolf $A$, Kreutzer $T$, et al. Long-term effect of intravitreal bevacizumab (avastin) in patients with chronic diffuse diabetic macular edema. Retina. 2008; 28(8):1053-60.

16. Kumar A, Sinha S. Intravitreal bevacizumab (Avastin) treat-ment of diffuse diabetic macular edema in an Indian populartion. Indian J Ophtalmol 2007;55:451-5.

17. Soheilian M, Ramezani A, Yaseri M, Mirdehghan SA, Obudi A, Bijanzadeh B. Initial macular thickness and response to treatment in diabetic macular edema. Retina. 2011;31:1564-73.

18. Bressler NM, Beaulieu WT, Maguire MG, Glassman AR, Blinder KJ, Bressler SB, et al.Diabetic Retinopathy Clinical Research Network. Early Response to Anti-Vascular Endothelial Growth Factor and Two-Year Outcomes Among Eyes With Diabetic Macular Edema in Protocol T. Am J Ophthalmol. 2018;195:93-100.

19. Arevalo JF, Lasave AF, $\mathrm{Wu}$ L, et all; Pan-American Collaborative Retina Study Group (PACORES): Intravitreal bevacizumab for diabetic macular oedema: 5-year results of the Pan-American Collaborative Retina Study group. $\mathrm{Br} J$ Ophthalmol. 2016; 100: 1605- 10.

20. Arevalo JF, Liu TYA; Pan-American Collaborative Retina Study Group (PACORES). Intravitreal Bevacizumab in Diabetic Retinopathy. Recommendations from the Pan-American Collaborative Retina Study Group (PACORES): The 2016 Knobloch Lecture. Asia Pac J Ophthalmol (Phila). 2018; 7: 36-9.

21. Jafri AS, Rehman A, Mirani AH, Memon S. Outcomes of intravitreal bevacizumab and macular photocoagulation for treatment of diabetic macular edema in a tertiary care eye hospital, Karachi. Pak J Med Sci. 2017;33:1215-9.

22. Kriechbaum K, Prager S, Mylonas G, Scholda C, Rainer G, Funk $M$, et al.; Diabetic Retinopathy Research Group. Intravitreal bevacizumab (Avastin) versus triamcinolone (Volon A) for treatment of diabetic macular edema: one-year results. Eye (Lond). 2014;28:9-15. 